\title{
Virtual water trade and development in Africa
}

\author{
M. Konar ${ }^{1}$ and K. K. Caylor ${ }^{2}$ \\ ${ }^{1}$ Department of Civil and Environmental Engineering, University of Illinois at Urbana-Champaign, Urbana, IL 61801, USA \\ ${ }^{2}$ Department of Civil and Environmental Engineering, Princeton University, Princeton, NJ 08544, USA
}

Correspondence to: M. Konar (mkonar@illinois.edu)

Received: 18 May 2013 - Published in Hydrol. Earth Syst. Sci. Discuss.: 6 June 2013

Revised: 13 August 2013 - Accepted: 5 September 2013 - Published: 15 October 2013

\begin{abstract}
A debate has long existed on the relationships between human population, natural resources, and development. Recent research has expanded this debate to include the impacts of trade; specifically, virtual water trade, or the water footprint of traded commodities. We conduct an empirical analysis of the relationships between virtual water trade, population, and development in Africa. We find that increases in virtual water imports do not lead to increases in population growth nor do they diminish human welfare. We establish a new index of virtual water trade openness and show that levels of undernourishment tend to fall with increased values of virtual water trade openness. Countries with small dam storage capacity obtain a higher fraction of their agricultural water requirements from external sources, which may indicate implicit "infrastructure sharing" across nations. Globally, increased crop exports tend to correlate with increased crop water use efficiency, though this relationship does not hold for Africa. However, internal African trade is much more efficient in terms of embodied water resources than any other region in the world. Thus, internal African trade patterns may be compensating for poor internal production systems.
\end{abstract}

\section{Introduction}

The debate on the relationship between human population growth, development, and natural resources dates back to Condorcet (1794) and Malthus (1798), and has been contributed to by other classic works (Jevons, 1865; Ehrlich, 1968; Simon, 1980). The now famous wager between Paul Ehrlich and Julian L. Simon centered on population growth and resource scarcity. Recently, this debate has been expanded to include the implications of increased access to natural resources through trade. In particular, recent works focus on water resources embodied in traded commodities (i.e. virtual water trade), and suggest that importing virtual water resources may encourage human population growth beyond a sustainable limit, eventually diminishing human welfare (D'Odorico et al., 2010; Suweis et al., 2013).

The quantity of resources embodied in international trade has been analyzed for a range of commodities, including land (Fader et al., 2011; Kastner et al., 2012), carbon (Peters et al., 2011), nutrients (Schipanski and Bennett, 2012), and water (Hoekstra and Hung, 2005). In this paper, we focus on freshwater resources embodied in the staple food trade. Trade links water and food systems (Konar et al., 2011), since food production is tightly coupled with water resource availability and use, in a "globalization of water" (Hoekstra and Chapagain, 2008). Our focus is on trade in staple agricultural products, since its impacts on agricultural production and food prices are important in understanding human welfare impacts in developing countries, such as Africa (Hertel et al., 2010).

Recent theoretical research suggests that increasing imports of virtual water resources may cause local human populations to grow beyond a sustainable limit, leading to a reduction in local food security (D'Odorico et al., 2010). However, in the economics literature, although a debate does exist, it is fairly well accepted that reliable access to natural resources slows population growth and that open economies improve development objectives (Frankel and Romer, 1999; Winters et al., 2004). For this reason, it has been suggested that trade liberalization can help to improve food security (Dorosh, 2001; Burgess and Donaldson, 2010) and human welfare (Winters et al., 2004). Agricultural markets are particularly complicated by high levels of distortion, such as government subsidies and barriers to trade (Peterson, 2009; Paarlberg, 2010), making the relationship between trade, food and water 
security, and human welfare unclear. In this paper, we examine the empirical evidence on the relationship between virtual water trade, population growth, and human development, with a particular focus on Africa.

Despite popular conceptions, Africa has a wealth of renewable freshwater resources, estimated at approximately $5400 \mathrm{~km}^{3}$ per year. This equates to roughly $6800 \mathrm{~m}^{3}$ per person per year (Odularu, 2009), compared with a per capita annual water availability of $2234 \mathrm{~m}^{3}$ in China (Hoekstra and Chapagain, 2008; Liu et al., 2013b). However, water resources are highly variable in both time and space across the African continent and agricultural production is predominantly rain-fed, due to low levels of irrigation infrastructure and dam storage capacity (e.g. approximately $4 \%$ of arable land is irrigated in Sub-Saharan Africa, compared with a global average of $20 \%$ (FAO, 2009)). Consequently, much of African agriculture is particularly vulnerable to weather conditions and climate variability (Rosegrant et al., 2002; FAO, 2011a).

Agricultural yield gains have been much lower in SubSaharan Africa than in other world regions (Godfray et al., 2010). For example, maize yields typically attain less than half of their potential throughout the region (Foley et al., 2011). This is largely due to the inadequacies of input and output markets, extension services, and infrastructure (FAO, 2009). Additionally, the Intergovernmental Panel on Climate Change estimates that climate change could cause crop yields on rainfed lands to decrease by $50 \%$ in some African countries, leading them to potentially spend $5-10 \%$ of GDP to adapt to a changing climate (IPCC, 2007). Estimates of the impacts of climate change on African crop yields have since been refined, with negative impacts still expected (Schlenker and Lobell, 2010), though positive gains may occur in the short term (Liu et al., 2013a). There is an urgent need for agricultural research in Africa, particularly research that focuses on opportunities for adaptation to climate change, yet agricultural research and development spending only grew at an average annual rate of $0.6 \%$ (FAO, 2009).

Reducing risk and vulnerability in agricultural production - especially to extreme weather events and price swings is necessary to facilitate poverty reduction in Africa, which is one of the Millennium Development Goals of the United Nations. Trade in agricultural products is one way to reduce vulnerability to domestic weather shocks in agricultural production (Burgess and Donaldson, 2010). However, trade in African nations exhibits high sensitivity to price fluctuations, which are anticipated to occur under climate change (Konar et al., 2013). These fluctuations in price and production have direct repercussions for welfare in the importer nations (Hertel et al., 2010).

Since 1980, agricultural imports have grown consistently faster than exports in Africa. Net food imports grew at an average rate of $3.4 \%$ per year between 1980 and 2007 and were primarily comprised of cereals and livestock products (FAO, 2011b). As long as other export sectors generate enough revenue to pay for food imports, this food import dependency may not pose a serious issue. This is because consumers in these countries benefit from the cheap food imports. However, recent spikes in food prices highlight challenges of expanding agricultural production in response to price increases. Projections to 2050 tend to confirm that African countries will remain dependent upon food imports, making it essential to better understand the impact of imports on food and water security, as well as other development objectives in Africa.

In this paper, we address the following questions using empirical data for African nations: (1) Does virtual water trade impact human population and development? (2) Is there a relationship between virtual water trade and food security? (3) What is the relationship between water resources infrastructure and virtual water trade? (4) Does agricultural trade impact crop water use efficiency? Our major findings are that increased virtual water imports do not lead to population growth, but do increase human welfare; increased virtual water trade is correlated with enhanced food security; countries with less dam storage capacity tend to consume a larger fraction of their agricultural water footprint from external sources; and that internal production systems in Africa do not show water use efficiency gains with increased exports, but that internal African trade is the most efficient region in the world. These results suggest that trade may be helping African nations to meet food and water security objectives.

\section{Methods}

In this section, we describe the national data sets that we use, our new index of virtual water trade openness, the model that we use to estimate crop water use, and how we quantify bilateral virtual water trade flows and savings.

\subsection{Cross-sectional data sources}

We obtained cross-sectional data from a variety of sources. Population data was collected for each country from 19602011 from the World Bank (World Bank, 2012). Human Development Index (HDI) data was collected for each country from 1980-2011 from the United Nations Development Programme (UNDP). Note that HDI data is available every $5 \mathrm{yr}$ from 1980-2005, but annually from 2006-2011. HDI measures the average achievements in a country in three basic dimensions of human development: (1) a long and healthy life, as measured by life expectancy at birth; (2) knowledge, as measured by school enrollment and adult literacy; and (3) standard of living, as measured by gross domestic product (GDP) per capita. We utilize HDI data, since it was developed as an indicator of aggregate human welfare (UNDP, 2012).

We obtained a variety of data on agriculture and water resources from the Aquastat Database of the Food 
and Agriculture Organization of the United Nations (FAO) (Aquastat, 2013). Namely, we obtain information on the dam storage capacity, area equipped for irrigation, and the number of undernourished people, for each country and all available years.

Dam storage capacity is defined as the total cumulative storage capacity of all dams in each country in $\mathrm{km}^{3}$. The value indicates the sum of the theoretical initial capacities of all dams, which does not change with time. However, the amount of water stored within any dam is likely less than the capacity due to silting. Data on the area equipped for irrigation is from all sources and measured in hectares. The number of undernourished people refers to the condition of people whose dietary energy consumption is continuously below a minimum dietary energy requirement for maintaining a healthy life and carrying out light physical activity. This value is provided per 1000 inhabitants.

Water footprint data was obtained from Hoekstra and Chapagain (2008). Specifically, from this source, we obtain data on crop evapotranspiration (for both national consumption and export), internal agricultural water footprint, external agricultural water footprint, and gross virtual water flows related to trade in food products.

The internal agricultural water footprint of a nation is defined as the volume of domestic water resources used to produce agricultural goods consumed by inhabitants of the country. It is equal to the total volume of domestic water resources used in agricultural production minus the volume of virtual water exported to other countries via agricultural commodities. The external agricultural water footprint of a country is defined to be the annual volume of water resources used in other countries to produce agricultural goods that are consumed by the inhabitants of the country in question. This value is equal to the virtual water imported through agricultural commodities minus the volume of virtual water exported to other countries. Both internal and external water footprints focus on the consumptive end use of the water resources.

Hoekstra and Chapagain (2008) consider gross virtual water trade flows associated with 285 crop products (covering 164 primary crops) and 123 livestock products (covering 8 animal categories: beef cattle, dairy cows, swine, sheep, goats, fowls/poultry, laying hens, and horses). These flows are based on an average for the years 1997-2001. Data on domestic crop evapotranspiration and gross virtual water flows were used in the calculation of our new index of virtual water trade openness, due to the large number of commodities considered.

\subsection{A new index of virtual water trade openness}

In economics, the classic definition of trade openness is defined as total trade as a percentage of total economic activity, where total economic activity is typically represented by gross domestic product (GDP). Thus, the classic definition of trade openness is

$\mathrm{TO}_{c}=\frac{\text { Imports }_{c}+\text { Exports }_{c}}{\mathrm{GDP}_{c}}$,

where TO refers to trade openness of country $c$, Imports refers to gross imports of goods and services in value terms of country $c$, Exports refers to gross imports of goods and services in value terms of country $c$, and total economic activity is proxied with GDP of country $c$. Thus, TO measures the proportion of economic activity encapsulated in trade; and, for this reason, has also been referred to as the trade share or trade intensity. Data on trade openness was obtained from the United Nations Conference on Trade and Development (UNCTD) (UNCTD, 2013).

We define a new index of virtual water trade openness (VWTO) to mirror the classical definition of trade openness based on financial value. In this way, the relative importance of virtual water trade within a nation is determined, controlling for differences in the size of different countries. Here, we define VWTO to be the total virtual water trade associated with crops divided by the total water use in agriculture. So, VWTO is defined as

$\mathrm{VWTO}_{c}=\frac{\mathrm{VWE}_{c}+\mathrm{VWI}_{c}}{\mathrm{ET}_{c}}$,

where VWTO refers to the virtual water trade openness of country $c$, VWE is the gross virtual water export associated with crops for country $c$, VWI is the gross virtual water import associated with crops for country $c$, and ET is the total domestic crop evapotranspiration associated with crops in country $c$. All of the variables that we use to construct this index were collected from Hoekstra and Chapagain (2008).

\subsection{Agricultural virtual water content estimates}

To obtain annual estimates of crop water use for each country we utilize the H08 global hydrological model (Hanasaki et al., 2008a, b, 2010). The model runs globally on a $0.5^{\circ} \times 0.5^{\circ}$ spatial grid and a daily time step. H08 incorporates human water use, energy and water balance closure, and consists of six modules: land surface hydrology, river routing, crop growth, reservoir operation, environmental flow requirements, and water withdrawal for human use (Hanasaki et al., 2010).

Land use and meteorological data are used to drive the H08 hydrology model. For land use, the global distribution of cropland (Ramankutty et al., 2008), major crops (Monfreda et al., 2008), irrigated areas (Siebert et al., 2005), and cropping intensity (Doll and Siebert, 2004) were used to run the model. These data were fixed to the year 2000 and were regridded for consistency with the spatial resolution of the meteorological forcing data. For meteorological data, the H08 model is forced with WATCH data (Weedon et al., 2011), available at a $0.5^{\circ}$ spatial resolution at $6 \mathrm{~h}$ intervals from 1901-2001. 
We use the H08 model to estimate annual values of total crop evapotranspiration $\overline{\mathrm{ET}}$. We obtain yearly data on crop yield from FAOSTAT (FAOSTAT, 2012). Although crop yield was an output of the H08 model, annual data from FAOSTAT (2012) was used for increased reliability. We combine this information to determine crop virtual water content (VWC) [dimensionless] of unprocessed crop commodities (i.e. barley, corn, rice, soy, and wheat). VWC is a countryspecific estimate of the volume of water used to produce a unit of agricultural output, given by

$\mathrm{VWC}_{e, c}=\frac{\overline{\mathrm{ET}}_{e, c}}{Y_{e, c}}$

where $\overline{\mathrm{ET}}$ is the evapotranspiration during a cropping period $\left(\mathrm{kg}_{\text {water }} \mathrm{m}^{-2}\right)$ and $Y$ is the crop yield $\left(\mathrm{kg}_{\text {crop }} \mathrm{m}^{-2}\right)$. The subscripts $\mathbf{e}$ and $\mathbf{c}$ denote the exporting country and crop, respectively.

The VWC of livestock is defined as the water consumption per head $\left[\mathrm{kg} \mathrm{head}^{-1}\right]$ divided by the total weight per head $\left[\mathrm{kg} \mathrm{head}^{-1}\right]$. We calculated the VWC [dimensionless] of unprocessed livestock products (i.e. beef, pork, and poultry) as

$\mathrm{VWC}_{e, l}=\frac{\mathrm{WC}_{e, l}}{P_{e, l}}$,

where WC is the water consumption per head of livestock $\left(\mathrm{kg}_{\text {water }}\right.$ head $\left.^{-1}\right)$ and $P$ is the livestock production per head $\left(\mathrm{kg}_{\text {livestock }}\right.$ head $\left.^{-1}\right)$. The subscripts $\mathbf{e}$ and $\mathbf{I}$ denote the exporting country and livestock product, respectively. WC was calculated by estimating the virtual water content of livestock feed. Next, the required livestock feed per head was estimated taking into account the life cycle of livestock. Then, water use other than feed, such as drinking and cleaning water was added (Hanasaki et al., 2008a, b, 2010).

From 1986-2001, VWC was calculated using the national crop yield time series data from FAOSTAT (FAOSTAT, 2012) and yearly estimates of $\overline{\mathrm{ET}}$ simulated with the H08 model. WATCH meteorological forcing data ends in 2001, so we utilize national crop yield statistics from the FAO (FAOSTAT, 2012) to obtain yearly estimates of VWC after 2001. Following Dalin et al. (2012) and Konar et al. (2012), we use the following equation:

$\mathrm{VWC}_{e, c, t}=\frac{\overline{\mathrm{ET}}_{e, c, 2001}}{Y_{e, c, t}}$,

where the subscripts $e, c$, and $t$ correspond to the country of production (and export), the unprocessed crop, and year, respectively. So, yearly $\overline{\mathrm{ET}}$ information is obtained from the H08 model from 1986-2001 and yearly VWC information is calculated according to Eq. (5) for the 2002-2008 period. Thus, from 2002-2008 annual changes in ET are not captured, other than through yield impacts.

\subsection{Bilateral trade data for staple food commodities}

We obtain data on the bilateral (i.e. link level) trade $(T)$ of staple food commodities from 1986-2008 from the FAO (FAOSTAT, 2012). Specifically, we obtained trade data on 58 commodities stemming from the unprocessed crop and livestock products for which we have yearly VWC estimates (i.e. barley, corn, rice, soy, wheat, beef, pork, and poultry). Note that these 58 commodities account for over $60 \%$ of global calorie consumption (FAOSTAT, 2012) and embody the majority of virtual water flows (Hoekstra and Hung, 2005; Hanjra and Qureshi, 2010).

A common problem with FAO trade data is that some countries report the final destination country, while others report the first destination. This makes it difficult to distinguish between export and re-export, which may be significant for some trade hubs, such as the United Arab Emirates (US Agricultural Trade Office, 2010). Due to this inconsistency, the virtual water trade of major trade hubs and those that process commodities for re-export may be overestimated in this analysis. In other words, it is impossible to distinguish production and consumption flows in all cases using FAO trade data.

\subsection{Quantifying virtual water trade flows and savings}

Bilateral trade data, in combination with estimates of VWC, allow us to quantify the virtual water trade (VWT) between two nations $e$ and $i$ in year $t$ by

$\mathrm{VWT}_{e, i, t}=\sum_{a} \mathrm{VWC}_{e, a, t} \cdot\left[\sum_{x \in a} \frac{p_{x} c_{x}}{r_{x}} \cdot T_{e, i, x, t}\right]$,

where the subscripts $e, i, t, a$, and $x$ denote the exporting country, importing country, year, agricultural item (i.e. unprocessed crop or livestock item), and commodity, respectively. The VWC of raw crops is transformed into that of a processed commodity by multiplying by the $p_{x} c_{x} / r_{x}$ coefficient, which does not vary in time. Values of $r, p$, and $c$ are specific to commodity $x$ and are provided for each of the 58 commodities in Appendix A. The price ratio $(p)$ is the ratio between the price of the raw crop and the price of the commodity produced from that raw crop. The content ratio $(c)$ indicates the percentage of a particular processed commodity that originates from the raw crop. The yield ratio $(r)$ quantifies the fraction of the raw crop that goes into the processed commodity (Hanasaki et al., 2010). The notation $x \in a$ indicates the ensemble of commodities that are produced from the raw agricultural item $a . T_{e, i, x, t}$ is the annual trade from exporting country $e$ to importing country $i$ of commodity $x$ in year $t$.

VWT is measured in $\mathrm{m}^{3} \mathrm{yr}^{-1}$ and aggregated over all commodities considered in the international food trade. Data on $T$ from the FAO is measured in tons $\mathrm{yr}^{-1}$ and VWC indicates $\mathrm{kg}_{\text {water }} / \mathrm{kg}_{\text {crop }}$. For water, $1 \mathrm{~m}^{3}$ is equivalent to $1000 \mathrm{~kg}$, or one ton, and one liter (or 1/1000 of a cubic meter) weighs 


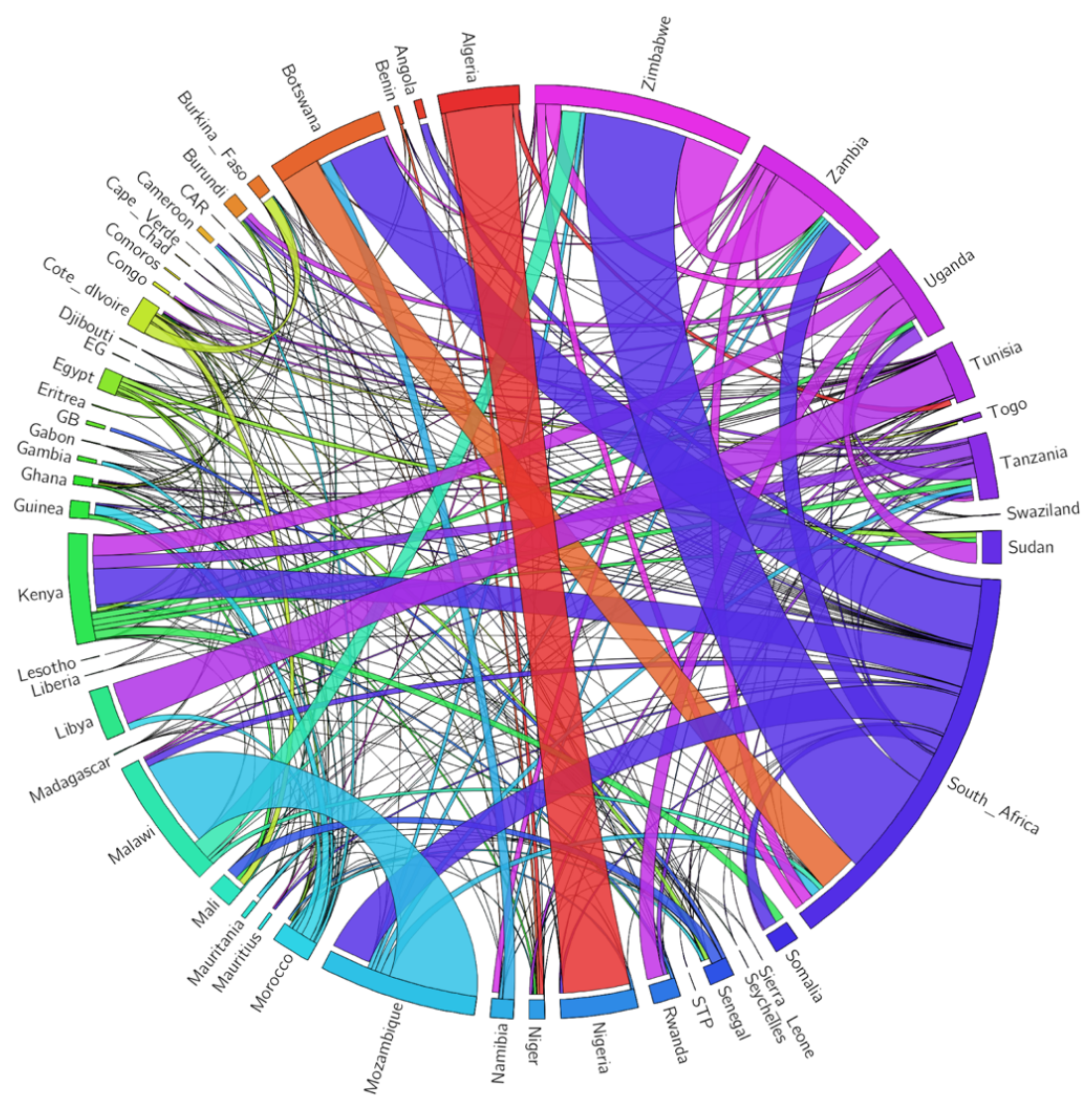

Fig. 1. African virtual water trade network. Each of the 51 African nations included in this graph is assigned a color. Trade links are assigned the same color as the country of export. Trade direction is indicated by the white gap between the trade link and the country of import. The total volume of virtual water trade within African countries is $3.59 \mathrm{~km}^{3}$. "CAR" indicates Central African Republic, "EG" indicates Equatorial Guinea, "GB" indicates Guinea-Bissau, and "STP” indicates Sao Tome and Principe.

$1 \mathrm{~kg}$. So, we obtain virtual water trade flows in $\mathrm{m}^{3}$ using the conversion: 1 ton crop $\cdot 1 \mathrm{~kg}$ water $/ 1 \mathrm{~kg}$ crop $\cdot\left(1 / 1000 \mathrm{~m}^{3}\right.$ water) $/ 1 \mathrm{~kg}$ crop $=1$ ton crop $/ 1000 \mathrm{~kg}$ crop $\cdot 1 \mathrm{~m}^{3}$ water $=1 \mathrm{~m}^{3}$ water.

Trade-based water savings (WS) is a theoretical measure of how much water is saved through trade. For each trade link, the water use efficiency of the country of export is subtracted from the water use efficiency of the country of import. The difference in water use efficiencies between trade partners is multiplied by the volume of crop trade occurring on that trade link. Positive values indicate that water is being saved by that trade link; Negative values indicate trade-based water losses. Regional water savings refer to the sum across all trade links within a particular region; global water savings sum all links in the world. We calculate WS by

$\mathrm{WS}_{e, i, c, t}=\sum_{x \in r} \mathrm{CT}_{e, i, c, t} \cdot\left(\mathrm{VWC}_{i, c, t}-\mathrm{VWC}_{e, c, t}\right)$,

where the subscripts $e, i, c$, and $t$ indicate exporting country, importing country, commodity, and year, respectively. The notation $x \in r$ indicates the ensemble of countries within region $r$, which may be all countries for the global calculation.

\section{Results and discussion}

\subsection{Virtual water trade, population, and development}

Figure 1 presents the internal African virtual water trade network in the year 2008. This network image aids in the visualization of large trade links, major exporters, and major importers. From Fig. 1 the virtual water trade from South Africa to Zimbabwe is shown as the largest link in the internal African network. This link represents $0.37 \mathrm{~km}^{3}$ of virtual water, which is approximately $10 \%$ of the total internal flow. South Africa stands out as a major exporter, which is not surprising given it has received more foreign direct investment than other parts of the continent, encouraging agricultural production at a large scale (Pearce, 2012). South Africa exports $1.12 \mathrm{~km}^{3}$ to other African nations. This is approximately $31 \%$ of total internal African trade. Zimbabwe is the major importer of virtual water resources (notice the large white gap associated with Zimbabwe in Fig. 1). Zimbabwe imports $0.66 \mathrm{~km}^{3}$ of virtual water, approximately $19 \%$ of internal flow. 

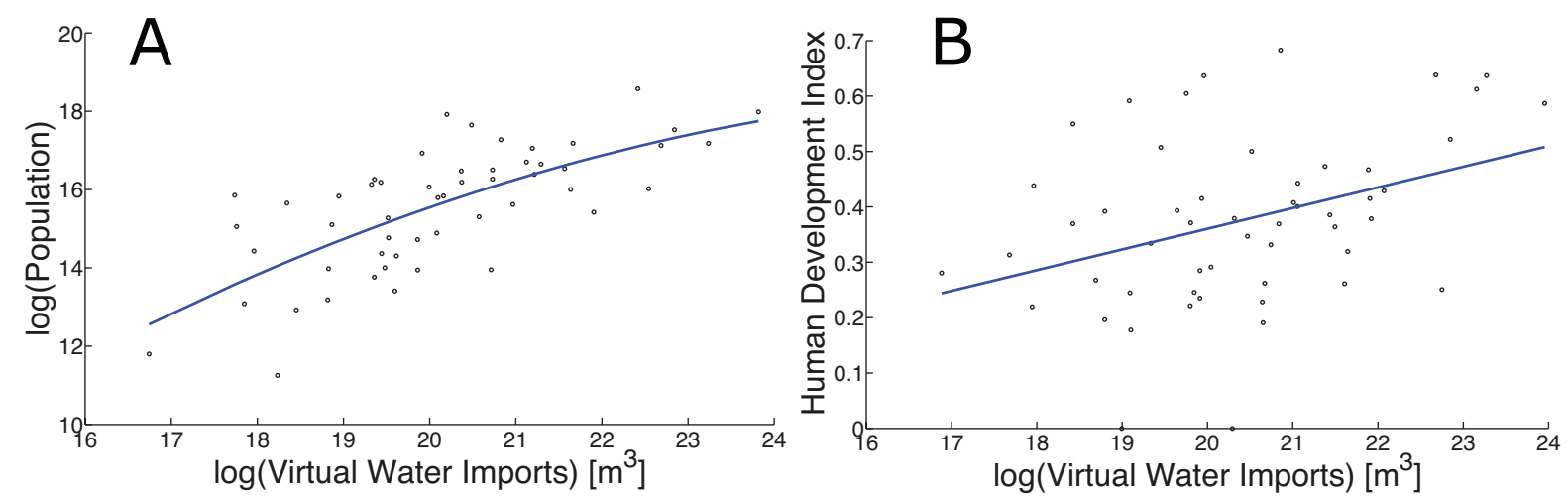

Fig. 2. Relationships for human population and development with virtual water imports (VWI) in Africa. (A) log(Population) against $\log$ (VWI) exhibits an increasing non-linear relationship. Note that the growth rate slows with increasing virtual water imports. (B) Human development index (HDI) against log (VWI) exhibits an increasing linear relationship. Each point represents the national time-average of available data between 1986 and 2008.

The total volume of virtual water trade within African countries is $3.59 \mathrm{~km}^{3}$. The total volume of trade from the rest of the world (ROW) to Africa is $61.67 \mathrm{~km}^{3}$. The total volume of trade from Africa to the ROW is $1.18 \mathrm{~km}^{3}$. So, although Africa does not export large volumes of virtual water to the ROW, countries in Africa trade over twice this volume amongst themselves. However, note that our commodity choice impacts our calculations of virtual water trade flows. This is particularly relevant for Islamic North Africa, which rarely participates in the trade of pork, due to cultural values and norms. Our analysis does not include sheep or goats, which countries in this region trade in larger volumes.

It makes sense that internal African trade is larger than African trade with the ROW, because countries that are close in distance to one another tend to trade more. In the international trade literature, a model often used to assess bilateral trade flows is the gravity model of trade, which states:

$T_{i, j}=c \frac{M_{i} M_{j}}{D_{i, j}}$,

where $T$ is the trade flow, $M$ is the economic mass of each country (typically GDP), $D$ is the distance between $i$ and $j$, and $c$ is a constant (Tinbergen, 1962). It has been shown that countries that are closer in geographic proximity to one another tend to trade larger volumes of virtual water. In fact, the average distance travelled by a unit of virtual water has decreased by approximately $1000 \mathrm{~km}$ between 1986 and 2010 (Tamea et al., 2013).

Recent research suggests that importing virtual water resources may encourage human population growth beyond a sustainable limit, eventually diminishing human welfare (D’Odorico et al., 2010; Suweis et al., 2013). To address this important issue, we consult panel data on population and human welfare. We present the relationship between $\log$ (population) and $\log$ (VWI) for Africa in Fig. 2a. The estimated regression line in Fig. 2a is given by $\log$ (Population)
$=-17.2+2.5 \cdot \log (\mathrm{VWI})-0.04 \cdot \log (\mathrm{VWI})^{2}$, where $R^{2}=$ 0.50 . From Fig. 2a, it is clear that $\log$ (population) increases in a non-linear way with the $\log (\mathrm{VWI})$. In other words, for each percentage increase in VWI there is a non-linear increase in percent population. However, note that this relationship levels off with increasing values of VWI. Thus, although there is a positive correlation between $\log$ (population) and $\log$ (VWI), the rate of population growth slows with increasing virtual water imports.

To better understand the relationship between human welfare and VWI, we plot HDI against $\log$ (VWI) in Fig. $2 b$ for Africa. From Fig. 2b, a linear relationship between HDI and $\log (\mathrm{VWI})$ is evident, where the estimated regression equation is given by HDI $=-0.4+0.04 \cdot \log (\mathrm{VWI})$, with $R^{2}=0.15$. This provides empirical evidence for an increase in human welfare with a percentage increase in VWI. However, this relationship is only a correlation, so no causal information can be inferred. Yet this empirical relationship does add another dimension to the current discussion on the relationship between virtual water trade and human development.

Since we only present correlations in Fig. 2, we are unable to distinguish reverse causality. It is possible that higher population levels are leading to increased virtual water imports, rather than virtual water imports leading to increased population. Similarly, enhanced human welfare may contribute to rising VWI, rather than the other way around. In an effort to address this issue with reverse causality, we consider lagged values of VWI and variables of interest. Both population and HDI are slow-moving variables, so a time lag should exist with current resource access. We select a time window of ten years. This time window is arbitrary, but should prove long enough to capture changes in these variables, but short enough to allow for analysis with our available data.

In Fig. 3a, we determine the current $\log$ (VWI) for each country from 1986-1990. Then, we determine the population 

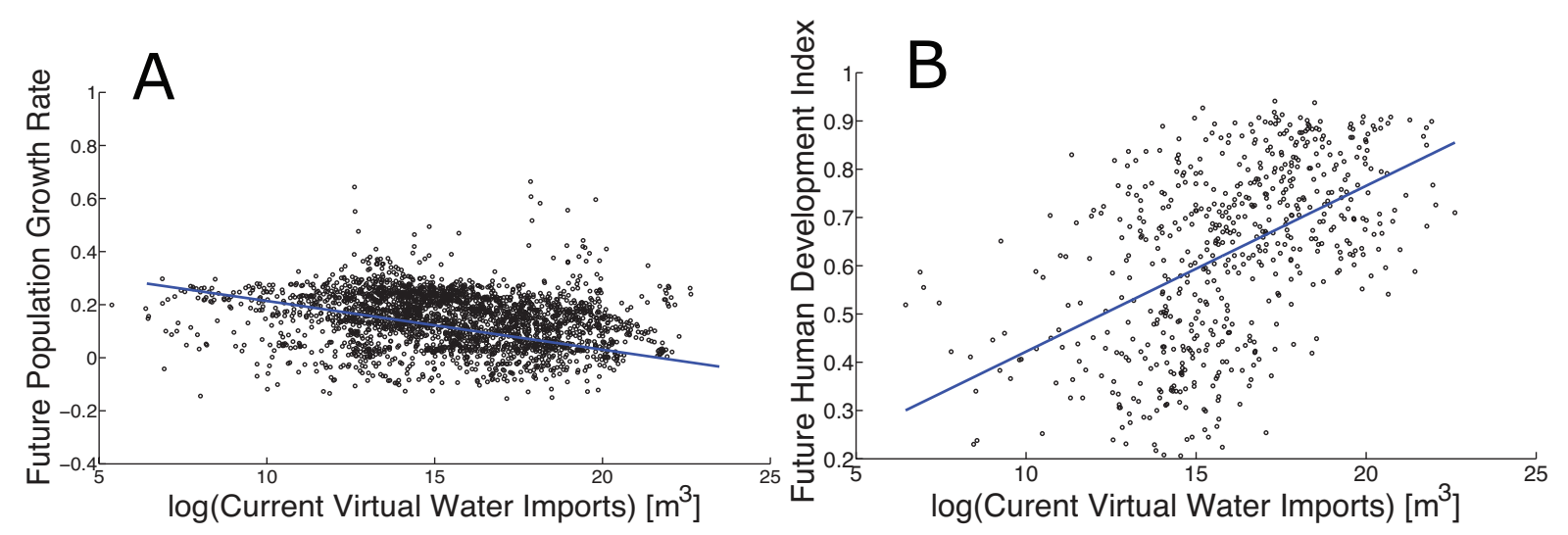

Fig. 3. Lagged global relationships for human population and development with virtual water imports (VWI). (A) Future population growth rate against current $\log$ (VWI) shows a linearly decreasing trend. (B) Future HDI exhibits a linearly increasing trend with current log (VWI). The time lag used is $10 \mathrm{yr}$.

growth rate ten years into the future. For example, a single data point represents the $\log (\mathrm{VWI})$ of South Africa in 1990 and the population growth rate of South Africa between 1990 and 2000. We plot this relationship for all countries in Fig. 3a. The estimated regression line in Fig. 3a is given by $r_{+10}=0.3-0.01 \cdot \log \left(\mathrm{VWI}_{0}\right)$, where the subscript +10 indicates a point $10 \mathrm{yr}$ in the future and the subscript 0 indicates the current value of VWI. The $R^{2}$ value for this relationship is 0.02 , which indicates little explanatory power between the two variables. However, the empirical relationship is provocative, since there is a decreasing trend between future population growth rates and percentage increases in current virtual water imports, which is opposite to what has previously been suggested in the literature. This relationship indicates that the current virtual water imports of a country are unlikely leading to increased population growth.

Similarly, in Fig. 3b, we determine the current $\log$ (VWI) for each country in the world. Then, we determine the HDI of each country in ten years. HDI data is only available every five years between 1985-2006, so this analysis consists of less data points than does Fig. 3a. The estimated regression equation is given by $\mathrm{HDI}_{+10}=-0.1+0.03 \cdot \log \left(\mathrm{VWI}_{0}\right)$, where the subscripts have the same meaning as in Fig. 3a. The $R^{2}$ value for this relationship is 0.20 . Thus, there is an increasing relationship between future HDI and percentage increases in current virtual water imports. This relationship indicates a positive correlation between current virtual water imports and future human well-being.

The relationships presented in Figs. 2 and 3 do not demonstrate causality. However, they do highlight that the relationship between virtual water trade, population, and development is likely more complex than previously suggested in the literature. Figure 3 presents an alternative narrative, in which increasing access to freshwater resources through trade tends to slow population growth and enhance human well-being. The idea that access to resources slows population growth, although counter-intuitive, has been documented in the literature for non-trade settings (UN Population Division, 1994).

\subsection{Food security and virtual water trade}

There is a debate in the literature on the relationship between trade and food security (Burgess and Donaldson, 2010; D'Odorico et al., 2010; Hanjra and Qureshi, 2010), particularly for African nations (Brown et al., 2009). In this section, we contribute to this discussion by assessing how trade openness impacts food security in Africa. Here, we use the fraction of the population that is undernourished as our proxy for food security.

The relationship between the fraction of the population that is undernourished and the classic index of trade openness is presented in Fig. 4a for Africa. This relationship exhibits a slight decreasing trend and is given by Percent Undernourished $=0.6-0.1 \cdot \log (\mathrm{TO})$. However, the explanatory power between these two variables is small, with $R^{2}=0.02$. Thus, the relationship between food security and the openness of a nation to trade is not easy to distinguish utilizing the classic definition of trade openness. This is likely because many of the factors considered in this definition do not directly relate to food production and consumption. Thus, a definition of trade openness that focuses on the trade in food and embodied water resources would aid our understanding, which is why we developed a new index of virtual water trade openness (VWTO; refer to Sect. 2.2).

We present the relationship between food security and our new VWTO index in Fig. 4b. In Fig. 4b, the relationship between the undernourished fraction and log index of VWTO displays a linearly decreasing relationship for Africa, given by the regression equation Percent Undernourished = $-0.2-0.1 \cdot \log (\mathrm{VWTO})$, where $R^{2}=0.38$. Note that the values on the $x$ axis in Fig. $4 \mathrm{~b}$ are smaller than they are for 

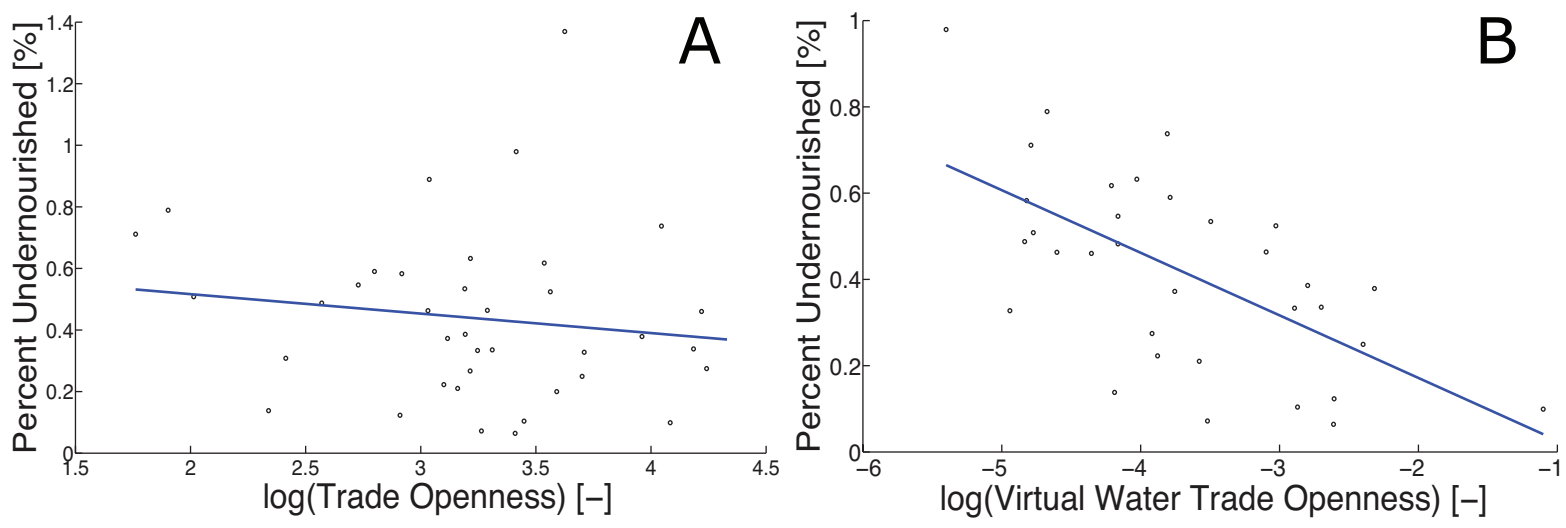

Fig. 4. Relationship between the fraction of the population that is undernourished and (A) the classic definition of trade openness based on financial value [i.e. USD]; and (B) the index of virtual water trade openness.

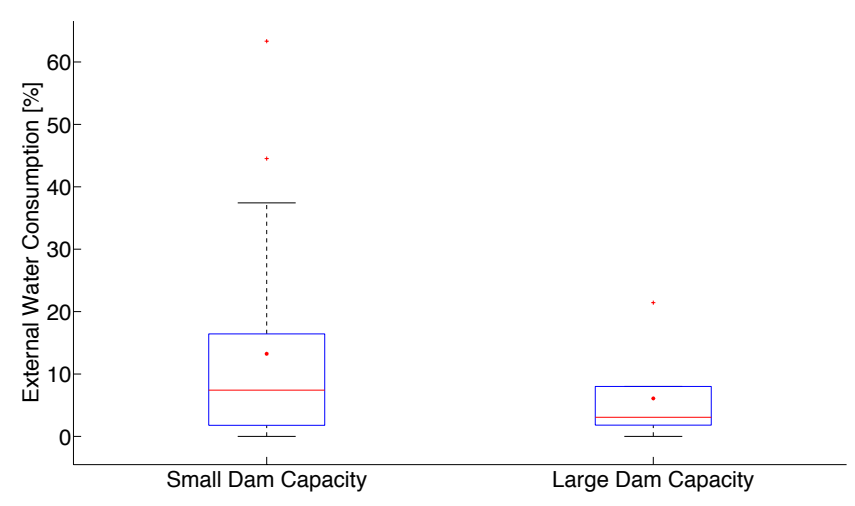

Fig. 5. Box-whisker plot of the external water consumption [\%] vs. the total storage capacity of each African nation. Small dam capacity is defined to be between 0 and $70 \mathrm{~km}^{3}$; large dam capacity is between 70 and $140 \mathrm{~km}^{3}$. The red horizontal line represents the median, while the mean is plotted with a red star. The edges of the box represent the 25 th and the 75 th percentiles of the data, while the whiskers extend to the most extreme data points that are not considered to be outliers. Data outliers are represented individually by red plus marks. Although the difference in means is not statistically significant, note the right skewed distribution of countries with a small dam capacity.

Fig. 4a. This is because African nations trade relatively small volumes of virtual water resources as a fraction of their domestic agricultural water use, when compared to the fraction of total trade in goods and services as a fraction of total economic activity.

\subsection{Virtual water trade and dam storage capacity}

Storage of water resources in dams is a way to mitigate against climate variability. Trade in food commodities and embodied water resources represents another opportunity to store water resources in time. African nations have relatively small dam storage capacity, when compared with the rest of the world. This lack in storage makes them vulnerable to climate variability. However, African nations may compensate for having less dam storage through other means, such as trading virtual water resources. In this section, we analyze the relationship between dam capacity and virtual water trade in Africa.

Dam storage capacity in African countries ranges from 0 to $140 \mathrm{~km}^{3}$. We divide countries into those with 0 to $70 \mathrm{~km}^{3}$, i.e. "small dam capacity", and those with 70 to $140 \mathrm{~km}^{3}$, or "large dam capacity". There are 38 countries with small dam capacity and 6 countries with large dam capacity in Africa. After categorizing African nations based on their dam storage capacity, we determine the proportion of a country's agricultural water footprint that originates from external sources. We present a box-whisker plot of this data in Fig. 5.

From Fig. 5 countries with small dam storage capacity appear to consume relatively more water resources from external sources (i.e. larger values of external water footprint) than do countries with large dam storage capacity. However, the difference in means between the small dam and large dam groups is statistically insignificant, largely due to the small number of countries contained within the large dam pool. Still, countries with small storage capacity exhibit high variance in the proportion of water consumption from external sources. This is exhibited by the large spread of the whiskers, particularly towards high values of external water consumption. Additionally, a few outliers in the distribution consume a much larger fraction of water resources from external sources.

The two data outliers in the small dam storage capacity group are Mauritius and Botswana. Mauritius has the highest external water consumption fraction (63\%), trailed by Botswana at $44 \%$. Mauritius has a dam storage capacity of $0.09 \mathrm{~km}^{3}$; Botswana's storage capacity is $0.45 \mathrm{~km}^{3}$. Several decades ago, about $90 \%$ of arable land in Mauritius was taken up by sugar cultivation. Sugar production has steadily declined in Mauritius, due to reductions in preferential trade 

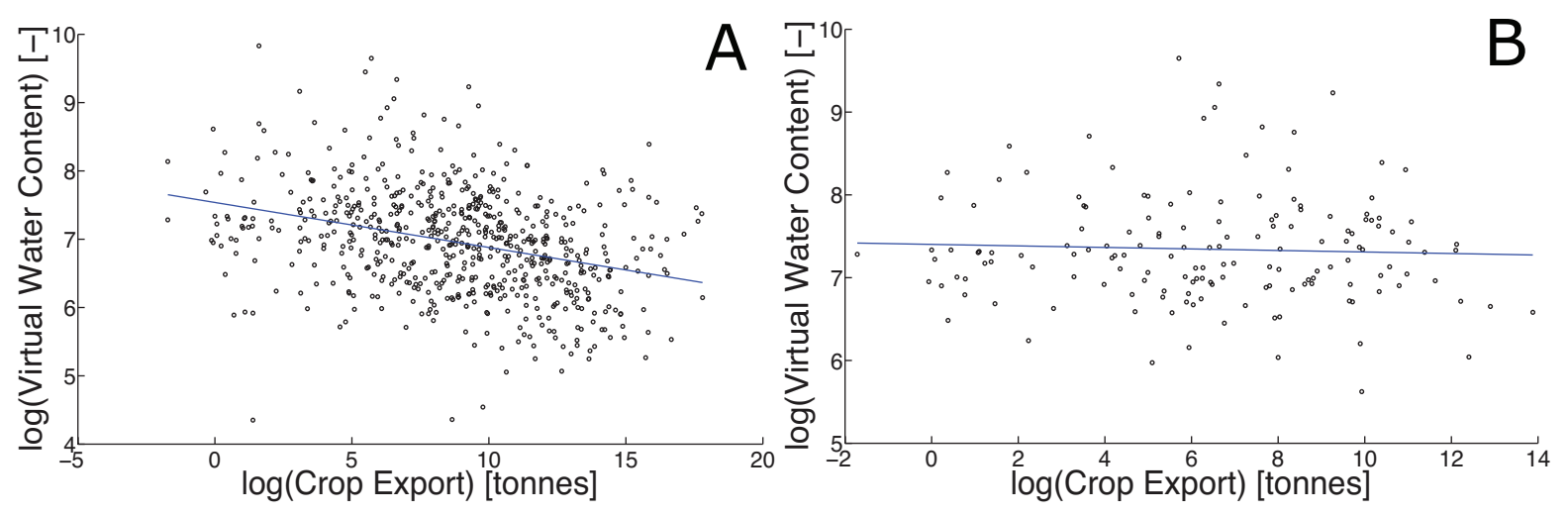

Fig. 6. Relationship between $\log$ VWC and $\log$ crop export for (A) the world and (B) Africa. Note that water use efficiency in agriculture increases (i.e. VWC decreases) in percentage terms with percentage increases in crop export for the world (A). However, the relationship between $\log$ VWC and log crop export is flat for Africa (B).

relationships with the EU. Fisheries have increased in importance as sugar production waned, accompanied by increased terrestrial crop imports (IFAD, 2005). Much of Botswana is part of the Kalahari Desert, a dry and drought-prone area, leading to low levels of domestic agricultural production. Crop production in Botswana is typically for internal consumption, but only meets a small fraction of national food requirements, leading to high levels of food import (IFAD, 2012).

The data outlier in the large dam capacity pool is Egypt, importing $21 \%$ from external sources, with a dam capacity of $168 \mathrm{~km}^{3}$. Note this does not imply that agricultural production in Egypt is not reliant upon upstream Nile water. Recall that the freshwater footprint considers the consumptive end use of the water used in agricultural production. Thus, agricultural commodities produced in Egypt, but exported and consumed elsewhere, will not count towards Egypt's external water footprint. Rather, this measure quantifies the water resources consumed by food imports in Egypt (refer to Hoekstra and Chapagain, 2008, for more details).

An interpretation of Fig. 5 is that countries with small storage capacity are able to obtain water resources to meet their consumptive demands through trade. The standard interpretation may be that countries with a large fraction of water consumption originating in external sources exhibit food vulnerability. However, we do not take this position. Our intention is not to use Fig. 5 to advocate for more dam storage.

Instead, it makes sense and may have positive implications that countries with small storage capacity are able to meet their agricultural water needs via external sources. We interpret this as infrastructure sharing. The concept of benefit sharing for large water infrastructure projects exists, but is typically applied in a formal setting to those organizations and individuals directly impacted by a specific project (Skinner et al., 2009). Through trade, countries are able to implicitly share dam infrastructure and the benefits associated with using dams in agricultural production, such as smoothing climate variability. Sharing infrastructure through trade means that not all countries have to undertake the massive financial and ecological expense associated with building a large dam.

\subsection{Crop water use efficiency and agricultural trade}

A potential benefit of trade is gains in agricultural water use efficiency. As countries increase agricultural exports, they may become more efficient in the use of factors of production, such as nutrients, labor, machinery, and water. In this section we explore the relationship between trade, agricultural water use, and trade-based water savings.

In Fig. 6, we plot the relationship between the log of VWC and the log of total staple crop export. This relationship is shown for all countries in the world in Fig. 6a and just for African nations in Fig. 6b. Globally, water use efficiency increases as crop exports increase (i.e. VWC decreases, indicating less water is used per unit of crop output). This estimated regression equation is given by $\log (\mathrm{VWC})=$ $7.5-0.1 \cdot \log (T)$, where $R^{2}=0.11$. In other words, for each percentage increase in crop export, there is a corresponding decrease in the percentage of water used in crop production at the global scale. However, for African nations, the estimated regression equation is $\log (\mathrm{VWC})=7.4-0.01 \cdot \log (T)$ and $R^{2}=0.002$. Thus, within Africa, there is no increase in water use efficiency with increased agricultural trade (refer to the flat relationship in Fig. 6b).

Tremendous opportunities exist to improve crop yields in Africa. Improved management of nutrient and water inputs has been suggested as a means to close "yield gaps" in Africa (Foley et al., 2011). Although agricultural production in Africa falls short of its potential, it is possible that some other facet of the agricultural systems is compensating for diminished yields. We investigate the possibility that the agricultural trade system within Africa demonstrates efficiencies unseen in its production system. 

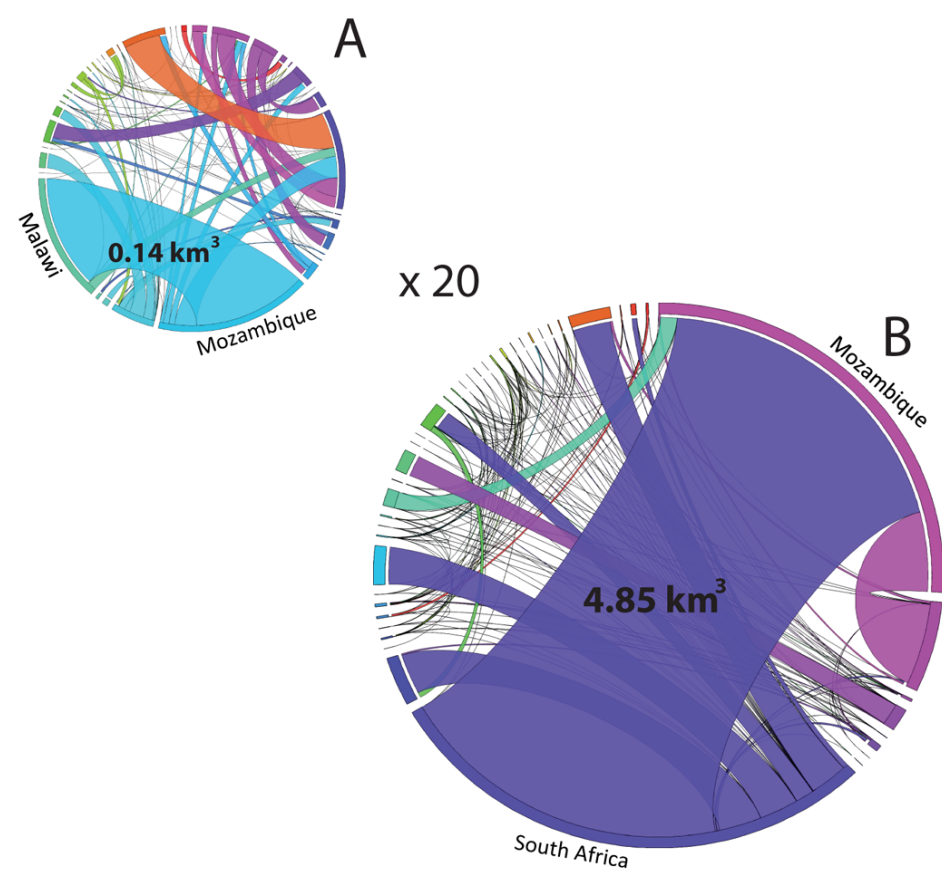

Fig. 7. Internal African (A) trade-based water losses and (B) trade-based water savings. Note that the regional graphs are not scaled by size, since internal African savings are approximately 20 times greater than losses.

Figure 1 shows the virtual water trade that takes place solely amongst African nations for the year 2008. This internal trade of food commodities represents $3.59 \mathrm{~km}^{3}$ of virtual water resources. This is the second smallest internal trade of all world regions (i.e. only Oceania trades less virtual water internally, with a volume of $1.08 \mathrm{~km}^{3}$; refer to Table 1). Although internal African trade is small, particularly relative to its land area, its trade-based water savings are average, with a volume of $9.14 \mathrm{~km}^{3}$ saved.

Trade-based water saving (WS) is a theoretical measure of how much water is actually used to produce traded commodities, compared with the water that would have been used had the importing nation produced the food themselves, maintaining all other factors equal. A trade link "saves" water resources when the food exporter uses less water to produce the crop output than the importer nation theoretically would have used. The volume of water saved is then calculated as this difference in VWC multiplied by the volume of food traded between countries. To quantify regional savings, all the trade links of a particular region are summed to obtain an estimate of internal trade-based savings.

Not all trade links save water. Trade often occurs between nations in which the importer could have produced the commodity with less water than the exporter used. This is because trade occurs for many reasons other than for water resources. Although trade does not occur due to water resources, it is useful to understand if particular trade links and the trade system as a whole is efficient in terms of water resources or not. Internal African trade loses $0.44 \mathrm{~km}^{3}$ per year.
The ratio of a region's internal WS to its total trade and water losses provide an estimate of its trade-based water efficiency. Figure 7 presents a network representation of efficiency in African agricultural trade. Trade-based losses are shown in Fig. 7a and savings in Fig. 7b. Note that the regional graphs are not scaled by the volume of water. To properly scale the African networks, the regional savings network provided in Fig. $7 \mathrm{~b}$ would need to be 20 times larger than the regional loss network provided in Fig. 7a. This scaling would make the regional loss network indistinguishable, so we indicate the fact that the water savings network is 20 times larger in text.

The largest links in the savings and losses networks can be seen in Fig. 7. The trade of food from Mozambique to Malawi amounts to trade-based water losses of $0.14 \mathrm{~km}^{3}$, which is approximately $32 \%$ of total internal African losses (refer to Fig. 7a). From Fig. 7b it is evident that trade from South Africa to Zimbabwe comprises the majority of the internal savings. The trade of food from South Africa to Zimbabwe is responsible for saving $4.85 \mathrm{~km}^{3}$, or approximately $53 \%$ of total internal African savings. Although this trade link dominates internal savings, the internal African network is still much more efficient than the global average without it (refer to Table 1).

Figure 8 maps the trade based water efficiency of each world region. From Fig. 8 it is clear that internal African trade is by far the most efficient regional virtual water trade system. Internal African savings are 2.5 times higher than total internal African trade. African WS amount to over 20 times more than losses. These numbers are significant when 


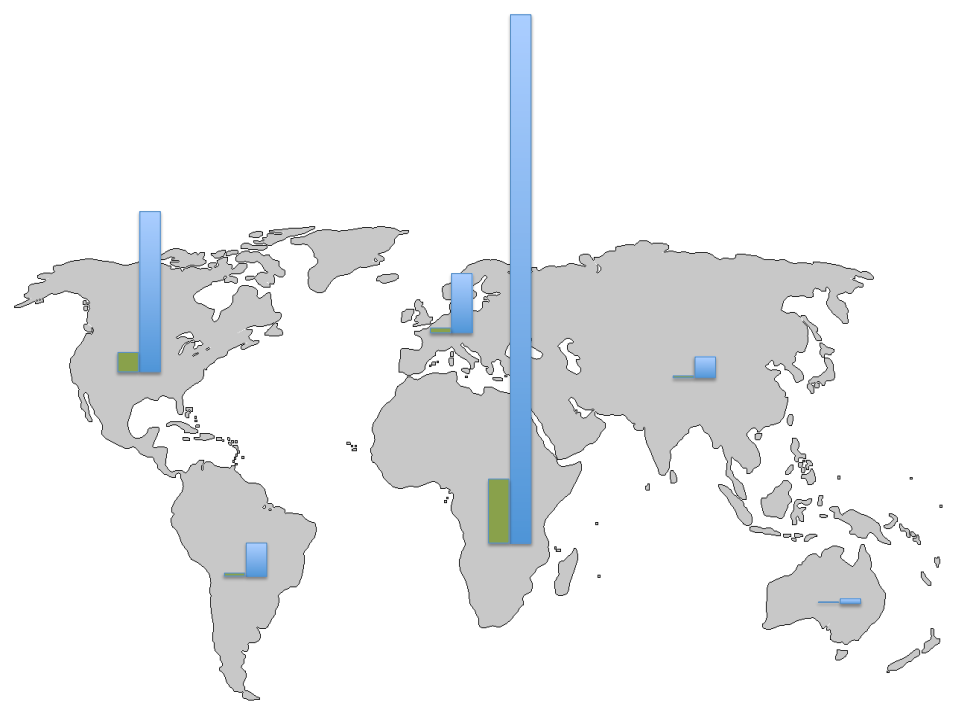

Fig. 8. World map displaying the ratios of regional water savings to trade and losses. The green bars indicate the water savings to trade ratios and the blue bars illustrate the water savings to losses ratios. Values of the regional ratios can be found in Table 1. Note that internal African trade is the most efficient in the world.

compared with other regions of the world. Globally, the ratio of savings to trade is 0.57 and the ratio of savings to losses is 5.20. However, this global average includes Africa, with values high above other world regions. When Africa is excluded from the average, the ratio of global savings to trade drops to 0.14 and the ratio of global savings to losses falls below 2 .

Thus, crop yields in Africa are low and present a major opportunity for future food production. Crop yields do not show efficiency gains with trade in Africa, though they do at the global scale. However, regional trade within Africa does demonstrate high levels of trade-based water saving and efficiency, with values far exceeding the global average. Since the African trade network is much more efficient in terms of embodied water resources than any other region in the world, internal African trade patterns may be compensating for poor internal production systems.

\section{Conclusions}

We contributed to the recent debate on the implications of increasing access to natural resources through trade for human population growth and development. To do this, we conducted an empirical analysis of panel data for Africa. We focused on Africa because this region has long been the subject of development debates. Additionally, this region is vulnerable to climate variability, due to small water storage capacities, and has been highlighted as an important focal point for increasing agricultural productivity. However, Africa is a vast continent with dramatic regional differences which we do not investigate in our continent-scale analysis, but instead leave to future work. Similarly, our commodity choice may have emphasized countries in Southern Africa, since countries in Northern Africa trade different goods.
We found that virtual water imports are unlikely leading to higher population growth rates. However, current virtual water imports are correlated with future increases in human development. Similarly, as a country becomes more open to virtual water trade, it experiences decreases in undernourishment, which we use to proxy food security gains. Of note, food security showed no correlation with the classic measure of trade openness in financial terms, but exhibited a strong relationship with the index of virtual water trade openness that we developed in this paper.

Countries with relatively large dam storage capacity consume less water resources from international sources. Although countries with small storage capacity consume more water from abroad, this does not indicate food vulnerability. Rather, these countries are accessing storage capacity through trade, in what can be thought of as infrastructure sharing. Implicitly sharing infrastructure through trade is efficient, in terms of minimizing the direct financial cost of building more dams, as well as the often heavy environmental and social costs of dam building.

Globally, countries tend to increase their crop water use efficiency as they export more crops. However, countries in Africa do not exhibit this trend. This confirms findings in the literature that yield gaps exist in Africa and that increasing internal agricultural production is a major challenge for the future. Despite low crop yields, regional agricultural trade in Africa exhibits high efficiency in terms of embodied water resources. African trade-based efficiencies are on the order of ten times higher than the global average. Thus, the agricultural trade system within Africa may be compensating to some extent for low levels of domestic productivity. 
Table 1. Regional virtual water trade, savings, and losses in $\mathrm{km}^{3}$ for 2008 . Regional African trade is the second smallest and savings are approximately average. However, note that the ratio of internal savings to trade in Africa is 2.55, while the global average without Africa is 0.14. Surprisingly, the ratio of African savings to losses is 20.77, while the global average, exclusive of Africa, is 1.74 .

\begin{tabular}{lrrrrr}
\hline & Trade $\left[\mathrm{km}^{3}\right]$ & Savings $\left[\mathrm{km}^{3}\right]$ & Losses $\left[\mathrm{km}^{3}\right]$ & Savings : Trade & Savings : Losses \\
\hline Africa & 3.59 & 9.14 & 0.44 & 2.55 & 20.77 \\
North America & 57.73 & 20.54 & 3.34 & 0.36 & 6.15 \\
South America & 44.43 & 6.20 & 5.83 & 0.14 & 1.06 \\
Asia & 75.70 & 10.11 & 20.23 & 0.13 & 0.50 \\
Europe & 46.84 & 9.34 & 3.56 & 0.20 & 2.62 \\
Oceania & 1.08 & 0.02 & 0.26 & 0.02 & 0.08 \\
World & 38.23 & 9.23 & 5.61 & 0.57 & 5.20 \\
\hline
\end{tabular}

\section{Appendix}

Table A1. List of commodities and the yield ratio $(r)$, price ratio $(p)$, and content ratio $(c)$; reproduced from Hanasaki et al. (2010).

\begin{tabular}{|c|c|c|c|c|c|c|c|}
\hline Crop commodities & $r$ & $p$ & $c$ & Livestock products & $r$ & $p$ & $c$ \\
\hline Wheat & 1 & 1 & 1 & Cattle meat & 0.6 & 0.61 & 1 \\
\hline Flour of wheat & 0.78 & 0.97 & 1 & Offal of cattle, edible & 0.32 & 0.38 & 1 \\
\hline Bran of wheat & 0.22 & 0.024 & 1 & Fat of cattle & 0.04 & 0.0024 & 1 \\
\hline Macaroni & 0.78 & 0.97 & 1 & Meat-cattle boneless (beef and veal) & 0.6 & 0.61 & 1 \\
\hline Germ of wheat & 0.025 & 0.01 & 1 & Cattle, butchered fat & 0.04 & 0.0024 & 1 \\
\hline Bread & 0.78 & 0.97 & 0.71 & Preparation of beef & 0.4 & 0.61 & 1 \\
\hline Bulgur & 1 & 1 & 1 & Pig meat & 0.7 & 0.88 & 1 \\
\hline Rice, paddy & 1 & 1 & 1 & Offal of pigs, edible & 0.12 & 0.12 & 1 \\
\hline Rice, husked & 0.72 & 1 & 1 & Fat of pigs & 0.06 & 0.006 & 1 \\
\hline Milled husked rice & 0.72 & 1 & 1 & Pork & 0.49 & 0.88 & 1 \\
\hline Rice, milled & 0.65 & 0.95 & 1 & Bacon and ham & 0.49 & 0.88 & 1 \\
\hline Rice, broken & 0.65 & 0.95 & 1 & Pig, butchered fat & 0.06 & 0.006 & 1 \\
\hline Bran of rice & 0.07 & 0.049 & 1 & Pork sausages & 0.49 & 0.88 & 1 \\
\hline Rice, bran oil & 0.013 & 0.049 & 1 & Prepared pig meat & 0.49 & 0.88 & 1 \\
\hline Cake rice bran & 0.057 & 0.049 & 1 & Lard & 0.06 & 0.006 & 1 \\
\hline Rice, flour & 0.65 & 0.95 & 1 & Chicken meat & 0.53 & 0.95 & 1 \\
\hline Rice, fermented beverages & 0.48 & 0.95 & 0.36 & Offal and liver of chicken & 0.022 & 0.014 & 1 \\
\hline Barley & 1 & 1 & 1 & Fat liver prepared (foie gras) & 0.022 & 0.014 & 1 \\
\hline Pot barley & 0.46 & 0.76 & 1 & Chicken meat canned & 0.53 & 0.95 & 1 \\
\hline Barley, pearled & 0.46 & 0.76 & 1 & Fat of poultry & 0.022 & 0.013 & 1 \\
\hline Bran of barley & 0.54 & 0.24 & 1 & Fat of poultry, rendered & 0.022 & 0.013 & 1 \\
\hline Barley flour and grits & 0.46 & 1 & 1 & & & & \\
\hline Malt & 0.78 & 1 & 1 & & & & \\
\hline Malt extract & 0.78 & 1 & 0.8 & & & & \\
\hline Beer of barley & 0.78 & 1 & 0.14 & & & & \\
\hline Maize & 1 & 1 & 1 & & & & \\
\hline Germ of maize & 0.115 & 0.18 & 1 & & & & \\
\hline Flour of maize & 0.8 & 0.75 & 1 & & & & \\
\hline Bran of maize & 0.085 & 0.068 & 1 & & & & \\
\hline Maize oil & 0.04 & 0.18 & 1 & & & & \\
\hline Cake of maize & 0.075 & 0.18 & 1 & & & & \\
\hline Soybeans & 1 & 1 & 1 & & & & \\
\hline Soybean oil & 0.19 & 0.35 & 1 & & & & \\
\hline Cake of soybeans & 0.76 & 0.65 & 1 & & & & \\
\hline Soya sauce & 0.76 & 0.65 & 0.17 & & & & \\
\hline Maize, green & 1 & 1 & 1 & & & & \\
\hline Maize for forage and silage & 1 & 1 & 1 & & & & \\
\hline
\end{tabular}


Acknowledgements. We would like to thank the data sources for making the data available, without which this project would not be possible. We thank the editor, Dieter Gerten, reviewer, Martin Keulertz, and one anonymous reviewer for their comments and suggestions, which greatly improved the paper.

Edited by: D. Gerten

\section{References}

Aquastat: Aquastat Database, Food and Agriculture Organization of the United Nations (FAO), available at: http://www.fao.org/ nr/water/aquastat/main/index.stm (last access: 15 March 2013), 2013.

Brown, M., Hintermann, B., and Higgins, N.: Markets, climate change, and food security in West Africa, Environ. Sci. Technol., 43, 8016-8020, 2009.

Burgess, R. and Donaldson, D.: Can openness mitigate the effects of weather shocks? Evidence from India's famine era, Am. Econ. Rev.: Papers and Proceedings, 449-453, 2010.

Condorcet, M.: Esquisse d'un tableau historique des progrés de l'espirit humain, Chez Agasse, 1794.

Dalin, C., Konar, M., Hanasaki, N., Rinaldo, A., and Rodriguez-Iturbe, I.: Evolution of the global virtual water trade network, P. Natl. Acad. Sci., 109, 5989-5994, doi:10.1073/pnas.1203176109, 2012.

D'Odorico, P., Laio, F., and Ridolfi, L.: Does globalization of water reduce societal resilience to drought?, Geophys. Res. Lett., 37, doi:10.1029/2010GL043167, 2010.

Doll, P. and Siebert, S.: Global modeling of irrigation water requirements, Water Resour. Res., 38, 8.1-8.10, doi:10.1029/2001WR000355, 2004.

Dorosh, P.: Trade liberalization and national food security: Rice trade between Bangladesh and India, World Development, 29, 673-389, 2001.

Ehrlich, P.: The Population Bomb, Vol. 208, Ballantine Books, 1968.

Fader, M., Gerten, D., Thammer, M., Heinke, J., Lotze-Campen, H., Lucht, W., and Cramer, W.: Internal and external green-blue agricultural water footprints of nations, and related water and land savings through trade, Hydrol. Earth Syst. Sci., 15, 1641-1660, doi:10.5194/hess-15-1641-2011, 2011.

FAO: How to feed the world 2050: High-level expert forum, The special challenge of Sub-Saharan Africa, Rome 12-13 October, 2009.

FAO: Climate change, water and food security, Food and Agriculture Organization of the United Nations (FAO) Water Reports 36, 1st Edn., 2011a.

FAO: Why has African become a net food importer? Explaining Africa agricultural and food trade deficits, Trade and Markets Division, Rome, 2011b.

FAOSTAT: Food and Agriculture Organization of the United Nations (FAO), available at: http://faostat.fao.org/, 2012.

Foley, J., Ramankutty, N., Brauman, K., Cassidy, E., Gerber, J., Johnston, M., Mueller, N., O'Connell, C., Ray, D., West, P., Balzer, C., Bennett, E., Carpenter, S., Hill, J., Monfreda, C., Polasky, S., Rockström, J., Sheehan, J., Siebert, S., Tilman, D., and Zaks, D.: Solutions for a cultivated planet, Nature, 478, 337-342, doi:10.1038/nature10452, 2011.
Frankel, J. and Romer, D.: Does trade cause growth?, Am. Econ. Rev., 89, 379-399, 1999.

Godfray, H., Beddington, J. R., Crute, I. R., Haddad, L., Lawrence, D., Muir, J. F., Pretty, J., Robinson, S., Thomas, S. M., and Toulmin, C.: Food security: The challenge of feeding 9 billion people, Science, 327, 812-818, doi:10.1126/science.1185383, 2010.

Hanasaki, N., Kanae, S., Oki, T., Masuda, K., Motoya, K., Shirakawa, N., Shen, Y., and Tanaka, K.: An integrated model for the assessment of global water resources - Part 2: Applications and assessments, Hydrol. Earth Syst. Sci., 12, 1027-1037, doi:10.5194/hess-12-1027-2008, 2008a.

Hanasaki, N., Kanae, S., Oki, T., Masuda, K., Motoya, K., Shirakawa, N., Shen, Y., and Tanaka, K.: An integrated model for the assessment of global water resources - Part 1: Model description and input meteorological forcing, Hydrol. Earth Syst. Sci., 12, 1007-1025, doi:10.5194/hess-12-1007-2008, 2008 b.

Hanasaki, N., Inuzuka, T., Kanae, S., and Oki, T.: An estimation of global virtual water flow and sources of water withdrawal for major crops and livestock products using a global hydrological model, J. Hydrol., 12, 823-848, doi:10.1175/2011JHM1369.1, 2010.

Hanjra, M. and Qureshi, M.: Global water crisis and future food security in an era of climate change, Food Pol., 35, 365-377, 2010.

Hertel, T., Burke, M., and Lobell, D.: The poverty implications of climate-induced crop yield changes by 2030, Global Environ. Change, 20, 577-585, 2010.

Hoekstra, A. and Chapagain, A.: Globalization of water: Sharing the planet's freshwater resources, Wiley-Blackwell, 224 pp., ISBN 978-1-4051-6335-4, 2008.

Hoekstra, A. and Hung, P.: Globalisation of water resources: international virtual water flows in relation to crop trade, Global Environ. Change, 15, 45-56, 2005.

IFAD: Republic of Mauritius: Country strategic opportunities paper, International Fund for Agricultural Development (IFAD), Rome 12-13 December, 2005.

IFAD: International Fund for Agricultural Development renews relationship with Botswana, available at: http://www.ifad.org/ media/press/2012/11.htm, 2012.

IPCC: Climate Change 2007: The Physical Basis. Contribution of Working Group I to the Fourth Assessment Report of the Intergovernmental Panel on Climate Change, Cambridge University Press, 2007.

Jevons, W.: The Coal Question; An Inquiry Concerning the Progress of the Nation, and the Probable Exhaustion of Our Coal Mines, Macmillan \& Co. London, 1865.

Kastner, T., Rivas, M., Koch, W., and Nonhebel, S.: Global changes in diets and the consequences for land requirements for food, P. Natl. Acad. Sci., 109, 6868-6872, doi:10.1073/pnas.1117054109, 2012.

Konar, M., Dalin, C., Suweis, S., Hanasaki, N., Rinaldo, A., and Rodriguez-Iturbe, I.: Water for food: The global virtual water trade network, Water Resour. Res., 47, W05520, doi:10.1029/2010WR010307, 2011.

Konar, M., Dalin, C., Hanasaki, N., Rinaldo, A., and RodriguezIturbe, I.: Temporal dynamics of blue and green virtual water trade networks, Water Resour. Res., 48, W07509, doi:10.1029/2012WR011959, 2012. 
Konar, M., Hussein, Z., Hanasaki, N., Mauzerall, D. L., and Rodriguez-Iturbe, I.: Virtual water trade flows and savings under climate change, Hydrol. Earth Syst. Sci., 17, 3219-3234, doi:10.5194/hess-17-3219-2013, 2013.

Liu, J., Folberth, C., Yang, H., R'ockström, J., Abbaspour, K., and Zehnder, A.: A global and spatially explicit assessment of climate change impacts on crop production and consumptive water use, PLOS One, 8, e57750, doi:10.1371/journal.pone.0057750, 2013a.

Liu, J., Zang, C., Tian, S., Liu, J., Yang, H., Jia, S., You, L., Liu, B., and Zhang, M.: Water conservancy projects in China: Achievements, challenges and way forward, Global Environ. Change, 23, 633-643, 2013b.

Malthus, T.: An essay on the principle of population, J. Johnson, London, 1798.

Monfreda, C., Ramankutty, N., and Foley, J.: Farming the planet, Part 2: The geographic distribution of crop areas and yields in the year 2000, Global Biogeochem. Cy., GB1022, doi:10.1029/2007GB002947, 2008.

Odularu, G.: Conceptual explanation of virtual water trade and lessons for Africa, Journal of Development and Agricultural Economics, 1, 162-167, 2009.

Paarlberg, R.: Food politics: What everyone needs to know, Oxford University Press, 1st Edn., 2010.

Pearce, F.: The land grabbers: The new fight over who owns the Earth, Beacon Press, 1st Edn., 2012.

Peters, G., Minx, J., Weber, C., and Edenhofer, O.: Growth in emission transfers via international trade from 1990 to 2008, P. Natl. Acad. Sci., 108, 8903-8908, doi:10.1073/pnas.1006388108, 2011.

Peterson, E. W. F.: A billion dollars a day: The economics and politics of agricultural subsidies, Wiley-Blackwell, 1st Edn., 2009.

Ramankutty, N., Evan, A., Monfreda, C., and Foley, J.: Farming the planet, Part 1: The geographic distribution of global agricultural lands in the year 2000, Global Biogeochem. Cy., GB1003, doi:10.1029/2007GB002952, 2008.

Rosegrant, M., Cai, X., and Cline, S.: World water and food to 2025, International Food Policy Research Institute, 1st Edn., 2002.

Schipanski, M. and Bennett, E.: The influence of agricultural trade and livestock production on the global phosphorus cycle, Ecosystems, 15, 256-268, doi:10.1007/s10021-011-9507-x, 2012.

Schlenker, W. and Lobell, D.: Robust negative impacts of climate change on African agriculture, Environ. Res. Lett., 5, 014010, doi:10.1088/1748-9326/5/1/014010, 2010.
Siebert, S., Döll, P., Hoogeveen, J., Faures, J.-M., Frenken, K., and Feick, S.: Development and validation of the global map of irrigation areas, Hydrol. Earth Syst. Sci., 9, 535-547, doi:10.5194/hess-9-535-2005, 2005.

Simon, J.: Resources, population, environment: an oversupply of false bad news, Science, 208, 1431-1437, doi:10.1126/science.7384784, 1980.

Skinner, J., Niasse, M., and Haas, L. (Eds.): Sharing the benefits of large dams in West Africa, Natural Resource Issues No. 19, International Institute for Environment and Development, 2009.

Suweis, S., Rinaldo, A., Maritan, A., and D'Odorico, P.: Watercontrolled wealth of nations, P. Natl. Acad. Sci., 110, 4230-4233, doi:10.1073/pnas.1222452110, 2013.

Tamea, S., Allamano, P., Carr, J. A., Claps, P., Laio, F., and Ridolfi, L.: Local and global perspectives on the virtual water trade, Hydrol. Earth Syst. Sci., 17, 1205-1215, doi:10.5194/hess-17-12052013, 2013.

Tinbergen, J.: An Analysis of World Trade Flows, in: Shaping the world economy, Twentieth Century Fund, 1962.

UN Population Division: Population and sustainable development, International conference on population and development, Cairo 5-13 September, 1994.

UNCTD: Statistical Database, United Nations Conference on Trade and Development, available at: http://unctadstat.unctad.org (last access: 15 March 2013), 2013.

UNDP: International Human Development Indicators, United Nations Development Programme, availabe at: http://hdrstats.undp. org/en/tables/ (last access: 15 March 2013), 2012.

US Agricultural Trade Office: Gulfood 2010 Briefing, available at: www.gulfoodusapavilion.com/Files/ATO\%20Dubai\% 20briefing.ppt (last access: 15 March 2013), 2010.

Weedon, G., Gomes, S., Viterbo, P., Shuttleworth, W., Blyth, E., Osterle, H., Adam, J., Bellouin, N., Boucher, O., and Best, M.: Creation of the WATCH forcing data and its use to assess global and regional reference crop evapotranspiration over land during the 20th century, J. Hydrometeorol., 384, 823-848, 2011.

Winters, L., McCulloch, N., and McKay, A.: Trade liberalization and poverty: The evidence so far, J. Econ. Lit., 42, 72-115, 2004.

World Bank: The World Bank Databank, available at: http:// databank.worldbank.org/data/ (last access: 15 March 2013), 2012. 